УДК 330.3

JEL Classification: P33, P45

http://doi.org/

Ю.В. Волкова

\title{
СУЧАСНІ ТЕНДЕНЦІЇ ІНВЕСТУВАННЯ ГОСПОДАРСЬКОЇ ДІЯЛЬНОСТІ ПІДПРИЕМСТВ
}

\begin{abstract}
Мета. Дослідження сучасного стану і структури капітальних інвестииій як в Украйні загалом, так $і$ в Донеиькому регіоні зокрема, у період 2011 - 2019 рр., визначення негативних тенденцій та перспектив, зазначення певних пропозицій щодо залучення інвестиційних ресурсів.

Методика. Методика дослідження загалом базується на методах системного аналізу, узагальнення і порівняння.

Результати. Було зазначені основні положення у формулювання поняття «інвестицї», наведено класифікаційну структуру інвестицій за різними ознаками. Було досліджено динаміку зміни обсягів капітальних інвестицій в економіку України, та, зокрема, в економіку Донецької області за період 2011 - 2019 рр.., щьо в свою чергу дозволили з'ясувати причини коливань показників. Проведений аналіз структури капітальних інвестицій за джерелами та видами економічної діяльності Донецької області, зроблені певні висновки щэодо змін, які відбулися в досліджуваний період. Надані рекомендації щодо поліпшення ефективності залучення інвестицій.

Наукова новизна. Наведені основні фактори, які стримують залучення інвестичій в економіку Украӥни, так $i$ в економіку Донецької області. Визначена найбільш пріоритетна галузь економіки регіону для інвесторів, проведений структурний аналіз капітальних інвестииій в економіку регіону дозволив з'ясувати за рахунок яких саме коштів підприємства оновлюють основні фонди. Зазначені певні пропозиції щฺодо ефективного залучення інвестицій. Обтрунтовано перспективи інвестування в начіональну економіку.
\end{abstract}

Практична значимість. Результати дослідження формують практичне підтрунтя для пошуку додаткових джерел інвестування господарської діяльності промислових підприємств на засадах сталості.

Ключові слова: джерела інвестиційних ресурсів, економічна діяльність, інвестиції, інвестиційний розвиток, клімат, сталий розвиток, структура, суб'єкти господарювання

Вступ. Стрімкий економічний розвиток багатьох країн, надає не менш потужні поштовхи для розвитку економіки нашої країни. Ці поштовхи мають на меті досягнення сталості за умови ефективного використання інвестиційних джерел. Що на даний час $€$ найголовнішою проблемою будь-якого підприємства. Саме інвестиції і $€$ тим структурним поштовхом для виведення України з економічної кризи.

Значні інвестиційні ресурси допоможуть підвищити рівень ефективності господарської діяльності підприємств країни. Актуальність визначеної теми полягає в визначенні необхідності залучення коштів до сталого розвитку суб'єктів господарювання, до підвищення рівня їх ефективної діяльності, до забезпечення їх економічного зростання, до стійкості результативних перетворень в рамках модернізації, до структурних перебудов i інновацій, до вирішення їх соціальних та екологічних проблем. Зазначені проблеми вимагають пошуку конкретно нових підходів до ведення ефективної господарської діяльності i точно визначає необхідність залучення інвестиційних ресурсів у будь-якій їх формі для довгострокового економічного розвитку підприємств.
Аналіз останніх досліджень i публікацій. Проблемами інвестицій, інвестиційної діяльності, інвестиційної активності, інвестиційного забезпечення, як на макро, так i на макрорівні, займалися й займається багато вчених, серед яких $\epsilon$ I. О. Бланк [1], В. М. Грідасов [2], Ю.І. Гришова [3], Д. Йоргенсон, Л. І. Катан [4], Дж. Кейнс, М. І. Кісіль [5], М. Ю. Коденська [6], Т. В. Майорова [7], А. А. Пересада [8], Т.В. Понедільчук [9], Т. Процик, В. Г. Федоренко [10], О. М. Царенко [11], У. Шарп [12], О. Ю. Шилова [13] та інші.. Аналіз робіт цих вчених дає змогу зрозуміти, що поняття інвестицій не втрачає своєї значущості й $\epsilon$ актуальним. Низка питань визначення джерел інвестиційних ресурсів та їх залучення $є$ невирішеними, тому є необхідність подальших досліджень у цьому напрямку.

Мета статті (постановка завдання). Метою даного дослідження $є$ 3'ясування джерел інвестиційного забезпечення сталого розвитку підприємств, їх визначення та перспективи як для України, так i для Донецької області.

Виклад основного матеріалу. Стабільний розвиток будь-якого підприємства залежить від ефективної політики управління інвестиційною діяльністю. Наразі, 
підприємства здійснюють свою господарську діяльність у досить не простих умовах, насамперед, це нестабільний інвестиційний клімат, недостатній об'єм інвестиційних ресурсів, нестійка макроекономічна ситуація, повільний розвиток ринкової інфраструктури. Таким чином, залучення інвестиційних ресурсів і ефективна інвестиційна діяльність має на меті пришвидшити впровадження сталого розвитку як економіки країни, так i окремих підприємств. Відмітимо, що чим більшим буде обсяг та вищою ефективність інвестиційних коштів, тим, відповідно й швидшим буде відтворюваний процес. В економічній діяльності будь-якого підприємства та й країни, інвестиції відіграють дуже важливу роль. Адже, саме інвестиції - це базис для оновлення матеріально-технічної бази підприємства, потужний поштовх до структурних змін на виробництві, впровадження інновацій, збалансованого стійкого розвитку підприємства в умовах глобальних трансформацій. На даний час для економіки нашої країни постає досить актуальне питання інвестування.

Інвестування відіграє значну роль у розвитку не лише економіки, регіонів, а й підприємств, оскільки це базис для:

- систематичного оновлення основних засобів виробництва;

- впровадження принципово-нових науково-технічних пропозицій;

- суттєвих структурних змін процесів господарської діяльності;

- впровадження принципів сталого розвитку господарської діяльності.

Отже, інвестування у господарську діяльність підприємства дозволить досягти змін у економічному розвитку діяльності цього підприємства, соціальному розвитку й не лишити осторонь екологічні проблеми. Таким чином, постає необхідність пошуку шляхів інвестування всіх позитивних змін у виробництві, але в умовах нинішньої кризи це досить не просто.

Як вже зазначалося, ефективне здійснення господарської діяльності потребує інвестицій, в той же час майбутні інвестори прагнуть у перспективі отримати достатній рівень прибутку. Але для цього необхідно чітко розуміти, що таке інвестиції і які бувають джерела і методи їх фінансування.
Аналізуючи наукову літературу, ми дійшли висновку, що існує багато трактувань поняття «інвестиції», різні трактування вищезгаданого терміну було розглянуто авторами в роботі [14]. Необхідно зауважити, що основним нормативно-правовим актом, який регулює інвестиційну діяльність в Україні, є Закон України «Про інвестиційну діяльність». Закон України «Про інвестиційну діяльність» визначає правові, економічні та соціальні передумови ведення інвестиційної діяльності. У вищезгаданому документі подано визначення поняття «інвестиції», а саме: «інвестиціями $є$ всі види майнових та інтелектуальних цінностей, що вкладаються в об'єкти підприємницької та інших видів діяльності, в результаті якої створюється прибуток (доход) та/або досягається соціальний та екологічний ефект» [15]. Зазначимо зі згаданої роботи [14] основне сформульоване твердження поняття «інвестиції» - це ефективний спосіб вкладення коштів або капіталів 3 метою їх збільшення та збереження ,що досягається через ефективну економічну діяльність, основною метою якої $є$ забезпечення найефективніших шляхів реалізації стратегії інвестора на окремих життєвих циклах підприємства».

Інвестиції у науковій i навчальній літературі класифікуються за багатьма ознаками. Класифікаційна структура наведена на рис. 1.

Необхідно зауважити, що 3 кожним роком Україна стає все більш інвестиційнопривабливою для інвесторів, про це свідчать дані рис. 2. Необхідно зауважити, що значне падіння обсягу прямих іноземних інвестицій спостерігалося в 2015 році і продовжувалося протягом трьох років, це пов'язано 3 політичною кризою в країні, високим рівнем корупції, неефективною політикою проведення економічних реформ. Це в свою чергу призводить до втрати конкурентоспроможності економіки, спад темпів виробництва, стрімке збільшення собівартості товарів, що виробляються. Але починаючи 32018 року ситуація 3 інвестуванням країн світу в економіку України почала декілька покращуватись і обсяг іноземних інвестицій в економіку поступово починає збільшуватись. Варто зазначити, що незначне збільшення надходжень все ж таки свідчить про недовіру іноземних інвесторів. 


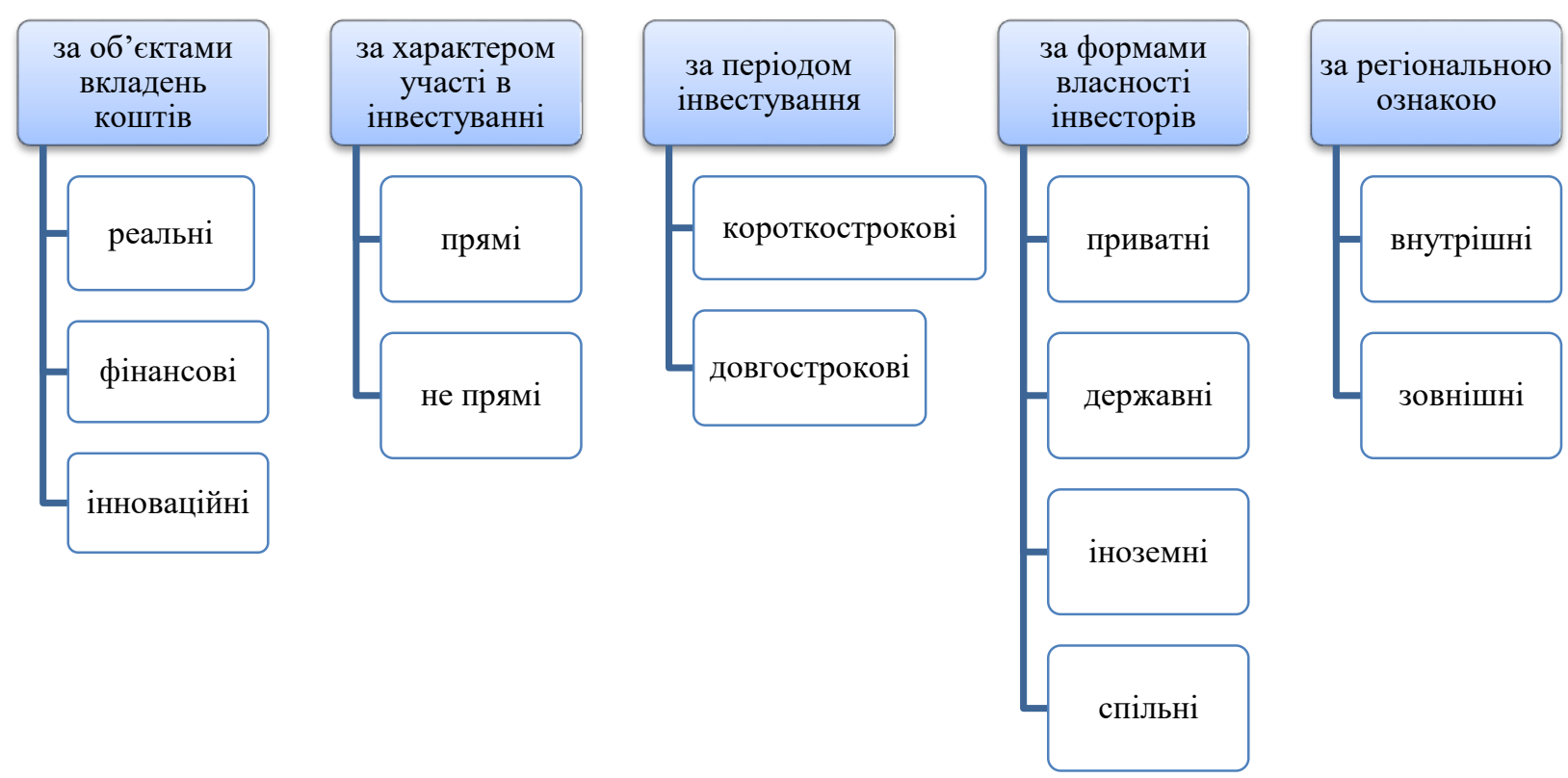

Рис. 1. Схематична класифікаційна структура інвестицій

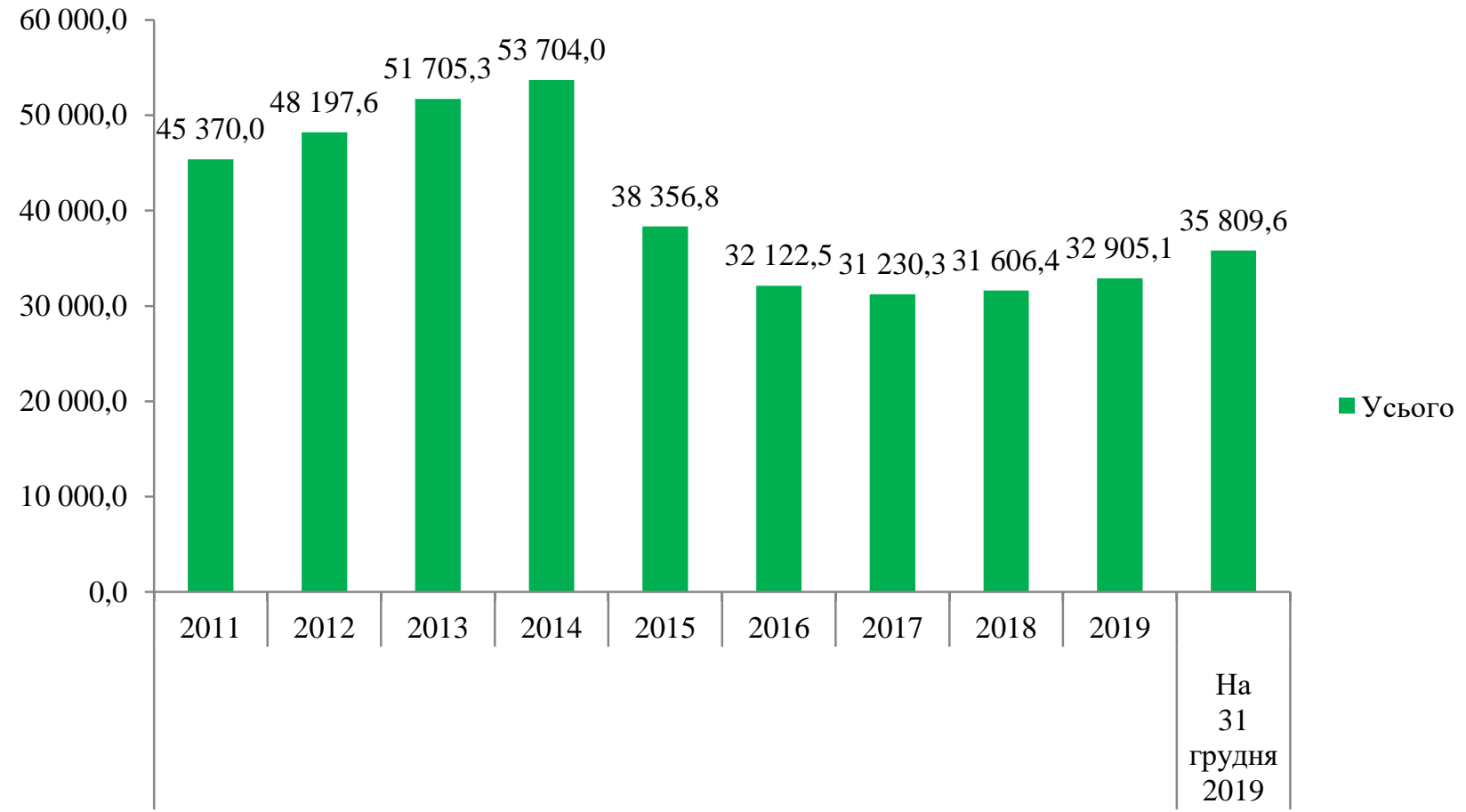

Примітка. Дані наведено без урахування тимчасово окупованої території Автономної Республіки Крим, м. Севастополя, станом на 01.01. 2014 та 2015 рр. - також без частини тимчасово окупованих територій у Донецькій та Луганській областях.

Рис. 2. Обсяги прямих інвестицій з країн світу в економіці України за період 2011-2019 рр. Джерело [16] 
3 метою активізації інвестування за забезпечення стійкого розвитку підприємства проведемо аналіз джерел фінансування капіталовкладень безпосередньо в Донецькій області. Але якщо більш детально розглянути динаміку капітальних інвестицій в Донецьку область (2011 - 2019 рр.) за джерелами надходжень та освоєння цих коштів за видами економічної діяльності (табл. 1) та рис. 3 можна дійти наступних висновків.

Як бачимо, тут, загалом до 2013 року, відстежується позитивна динаміка, тобто щороку розмір капітальних інвестицій збільшується. Починаючи 32014 року обсяги капітальних інвестицій суттєво знизилися. Це пояснюється окупацією певних територій Донецької області, озброєним військовим конфліктом, нестабільною політичною ситуацією, зміною керівництва країни, стрімким коливання курсу національної валюти. Відповідно інвестори, розуміючи, всі ризики не поспішають вкладати свої кошти. Але 3 2017 року спостерігається певна стабілізація ситуації. Конфлікт у Донецькій області не скінчився, але поступово політична ситуація стабілізувалася, керівництво поступово проводить реформи, приймає життєво необхідні закони для провадження економічної діяльності, намагається викорінити корупцію, а отже довіра інвесторів поступово відновлюється, й інвестори готові так би мовити «допомагати» економіці. Що стосується джерел фінансування капітальних інвестицій в Донецькій області, то загалом це власні кошти підприємств та організацій,

Але все ж таки головним джерелом фінансування капітальних інвестицій протягом досліджуваного періоду є власні кошти підприємств та організацій (див. рис.4.). Отже, обсяги інвестування напряму залежать від об'ємів прибутку підприємства. Відмітимо, що спостерігається позитивна тенденція до збільшення частки капітальний інвестицій за рахунок коштів державного бюджету, таки існує підтримка підприємств, за рахунок місцевих бюджетів - що зумовлене реформою децентралізації й передачею фінансових ресурсів громадам, за рахунок кредитів банків - отже, банки також намагаються створити найбільш сприятливі умови для можливостей кредитування інвестиційних проектів.

Таблиця 1 - Капітальні інвестиції в економіку Донецької області за джерелами фінансування за період 2011 - 2019 рр. (тис. грн.)

\begin{tabular}{|c|c|c|c|c|c|c|c|c|c|}
\hline роки & 2011 & 2012 & 2013 & 2014 & 2015 & 2016 & 2017 & 2018 & 2019 \\
\hline 1 & 2 & 3 & 4 & 5 & 6 & 7 & 8 & 9 & 10 \\
\hline Усього & 26802044 & 31721911 & 27912408 & 13155270 & 8304350 & 11902168 & 17268944 & 26979391 & 30594456 \\
\hline $\begin{array}{lr}\text { у т.ч. } \\
\text { рахунок }\end{array}$ & & & & & & & & & \\
\hline $\begin{array}{l}\text { коштів } \\
\text { державного } \\
\text { Бюджету }\end{array}$ & 2641154 & 3714085 & 1090962 & 153984 & 142641 & 203030 & 298628 & 628597 & 1976995 \\
\hline $\begin{array}{l}\text { коштів } \\
\text { місцевих } \\
\text { бюджетів }\end{array}$ & 1164826 & 1216242 & 648184 & 349405 & 417831 & 1039958 & 1955739 & 3675999 & 3301182 \\
\hline $\begin{array}{l}\text { власних } \\
\text { коштів під-ств } \\
\text { та організацій }\end{array}$ & 17644479 & 21347143 & 21561143 & 11928354 & 7434538 & 10470984 & 14661747 & 22290250 & 24868946 \\
\hline $\begin{array}{l}\text { кредитів } \\
\text { банків та } \\
\text { інших позик }\end{array}$ & 4510342 & 4386545 & 3525700 & 329890 & 125463 & 102280 & 156588 & 234857 & 338966 \\
\hline $\begin{array}{l}\text { коштів } \\
\text { інвесторів- } \\
\text { нерезидентів }\end{array}$ & 79159 & $\kappa$ & 18740 & к & 5847 & 1850 & к & 29729 & к \\
\hline
\end{tabular}


Продовження таблиці 1

\begin{tabular}{|l|c|c|c|c|c|c|c|c|c|}
\hline \multicolumn{1}{|c|}{1} & 2 & 3 & 4 & 5 & 6 & 7 & 8 & 9 & 10 \\
\hline $\begin{array}{l}\text { коштів } \\
\begin{array}{l}\text { населення на } \\
\text { будівництво } \\
\text { житла }\end{array}\end{array}$ & 492820 & к & 889913 & 306967 & 39225 & 82065 & 119692 & 87862 & 67611 \\
\hline $\begin{array}{l}\text { інших джерел } \\
\text { фінансування }\end{array}$ & 269264 & 243926 & 177766 & к & 138805 & 2001 & к & 32097 & к \\
\hline
\end{tabular}

Примітка:

1. За 2014-2019 роки без урахування частини тимчасово окупованої території у Донецькій області.

2. к - дані не оприлюднюються з метою забезпечення виконання вимог Закону України "Про державну статистику" щодо конфіденційності статистичної інформації.

Дюерело [17] .

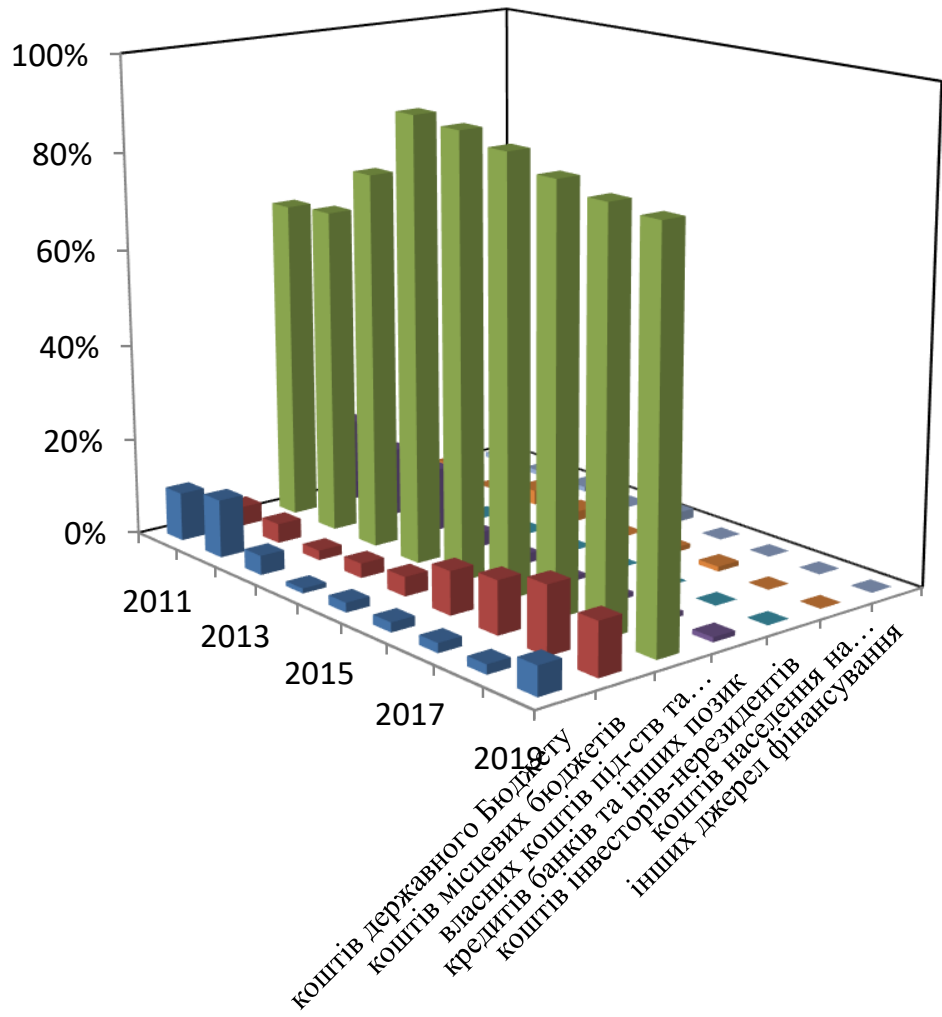

п коштів державного Бюджету

п коштів місцевих бюджетів

власних коштів під-ств та організацій

предитів банків та інших позик

- коштів інвесторів-нерезидентів

коштів населення на будівництво житла

च інших джерел фінансування

Рис. 3. Структура капітальних інвестицій в економіку Донецької області за джерелами фінансування за період 2011- 2019 рр.

Джерело [17]

Щодо структури капітальних інвестицій за видами економічної діяльності в Донецькій області, можна зробити висновок, що найбільш привабливими сферами економіки даного регіону для іноземних інвесторів $€$ галузь промисловості, також привабливими є оптова та роздрібна торгівля, операції 3 нерухомим майном, а саме будівництво, також осторонь не залишається й транспортна діяльність та поштова й кур'єрська доставка. Варто зауважити, що 
відбувся приріст інвестицій з 2015 року у сільське господарство, але починаючи 3 2018 року зменшується частка інвестування.

Також варто вказати, що серед регіонів України за показником обсягів капітальних інвестицій за розрахунками Державної служби статистики за період січень - грудень 2019 [16] посідає третю лідерську позицію. А за найбільшим обсягом капітальних інвестицій, саме за рахунок власних коштів підприємств, Донецька область серед інших регіонів посідає другу лідерську позицію. Це свідчить про те, суб'єкти господарювання, акумулюючи власні кошти, вкладають їх перспективний стійкий розвиток i оновлення матеріально- технічної бази, що в сою чергу має позитивну вплинути на інвесторів.

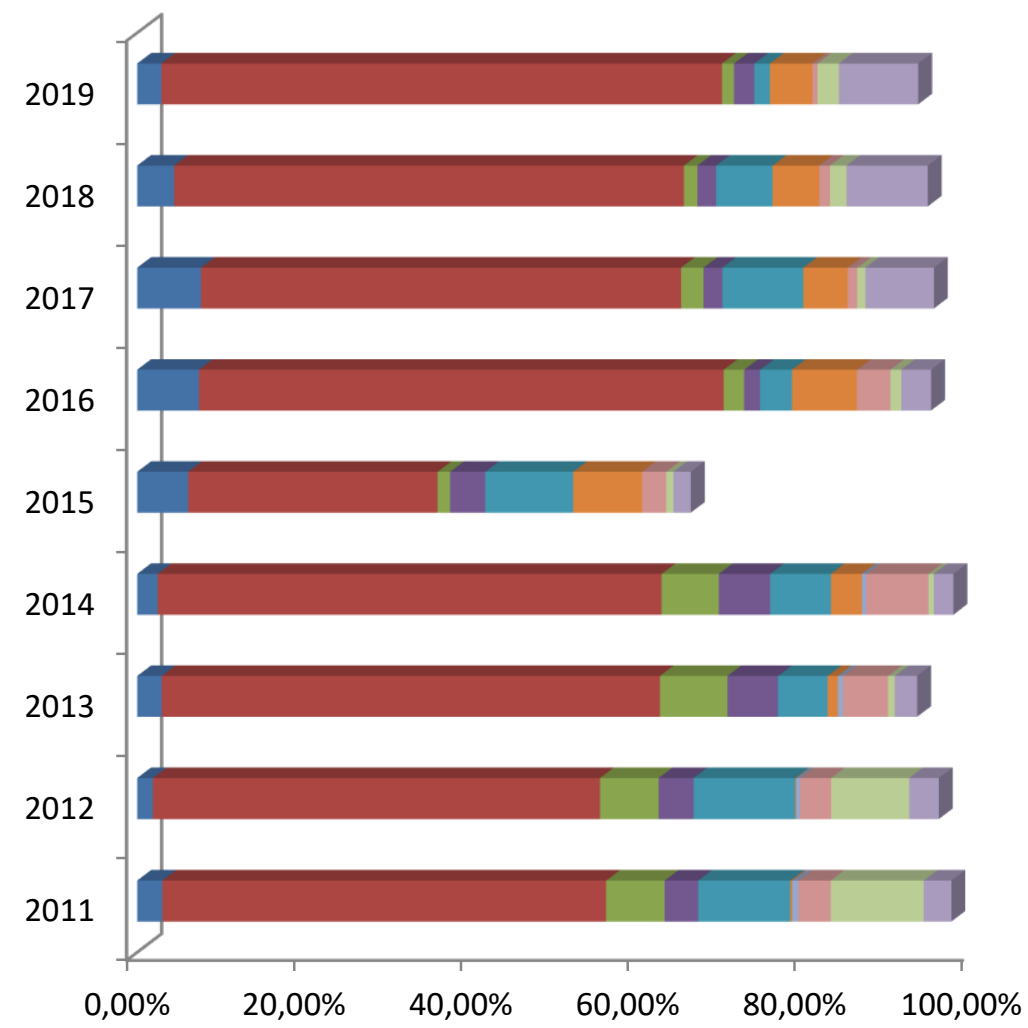

- Сільське господарство, лісове господарство та рибне господарство

П Промисловість

Б Будівництво

- Оптова та роздрібна торгівля; ремонт автотранспортних засобів і мотоциклів

- Транспорт, складське господарство, поштова та кур'єрська діяльність

п Інформація та телекомунікації

Фінансова та страхова діяльність

- Операції з нерухомим майном

Професійна, наукова та технічна діяльність

- Державне управління й оборона; обов'язкове соціальне страхування

Рис. 4. Структура капітальних інвестицій в економіку Донецької області за видами економічної діяльності за період 2011- 2019 рр.

Джерело [18]

Проведений аналіз дає зрозуміти, що саме інвестиції, поєднуючи в собі різні види капіталу забезпечують доступ до сучасних технологій, сприяють пришвидшенню розвитку ринку товарів і послуг, сприяють стабілізації макроекономічної ситуації, як на підприємстві, в регіоні, так і в цілому в економіці, також вони формують інвестиційні ринки, сприяють розвитку інфраструктури.

Крім цього, інвестиції дають змогу вирішувати питання сталого розвитку господарюючих суб'єктів сучасних економічних умовах.

Крім того варто додати, що на даному етапі функціонування підприємства, його виробничий потенціал, ефективна здійснювана діяльність прямо пропорційно залежить від інвестиційних рішень.

Висновки. Отже, аналізуючи стан інвестиційного забезпечення Донецького регіону можливо зробити наступний висновок, що серед регіонів країни, саме Донеччина $\epsilon$ найбільш привабливим, 
найбільший обсяг інвестування припадає на промисловість.

Як вже зрозуміло, ефективне провадження економічної діяльності суб'єктів господарювання переважно характеризується обсягом здійснюваних інвестицій. Інвестування забезпечує здійснення ключових моментів у виробничих процесах господарювання підприємств. Саме завдяки значним фінансовим вливанням можливе оновлення фондів суб'єктів господарювання, вихід на нові ринки, застосування нових практик виробництва; реалізація великих інноваційних проектів, створення нових робочих місць. Інвестиційні ресурси сприятимуть впровадженню політики сталого розвитку на підприємстві. Також інвестування в регіон сприятиме виходу підприємств на зовнішні ринки. Інвестиційні ресурси сприятимуть підвищенню інвестиційного іміджу регіону як в країні, так і за їі межами.

\section{Список літератури}

1. Бланк I.O. , Гуляєва H.M. Інвестиційний менеджмент: підручник. К.: Київ. нац. торг.- екон. ун-т, 2003. $398 \mathrm{c}$.

2. Грідасов В.М., Кривченко С.В., Ісаєва О.Є. Інвестування. К.: Центр навч. літ-ри, 2004. 164 с.

3. Гришова І. Ю., Стоянова-Коваль С. С. Інвестування стратегій інноваційного розвитку суб'єктів аграрної сфери України. Вісник Сумського національного аграрного університету. Серія : Економіка $i$ менеджмент. 2016. Вип. 4. C. 11-15. URL: http://nbuv.gov.ua/UJRN/Vsna_ekon_2016_4_ 4.

4. Катан Л. І., Хорішко К. С. Інвестиції та інвестування як економічна категорія. Ефективна економіка. 2011. № 11. URL: http://nbuv.gov.ua/UJRN/efek_2011_11_32 .

5. Кісіль М.I. Сучасні виклики, стратегічні пріоритети та завдання щодо інвестиційного забезпечення розвитку сільського господарства. Інноваиійна економіка. 2014. № 50. С. 14 - 19.

6. Коденська М. Ю. Мотиваційні чинники інвестиційного забезпечення розвитку аграрно-промислового
На погляд авторів, $є$ декілька перспективних пропозицій для більш ефективного залучення інвестицій:

$$
\text { стабілізація політичної }
$$

ситуації в регіоні, так і в цілому в країні;

$$
\text { - дотримання стабільного }
$$

валютного курсу гривні;

створення сприятливого

інвестиційного клімату, шляхом прийняття необхідних змін у законодавстві;

- створення й впровадження певної мотиваційної системи залучення інвестиційних коштів; створення інвестиційноінноваційної інфраструктури;

$$
\text { - налагодження відносин між }
$$
державою і бізнес-структурами.

Для успішного вирішення проблеми залучення та реалізації інвестицій суб'єктами господарювання необхідно, перш за все, визначити джерело фінансування інвестиційних коштів і вже на його основі проводити оцінку ефективності інвестиційної діяльності на підприємстві.

виробництва. Вісник Академії праці $i$ соціальних відносин Федераиії профспілок України. 2013. № 2. С. 62-66. URL: http://nbuv.gov.ua/UJRN/VAPSV_2013_2_11

7. Майорова Т.В. , Крук В.В., Шевчук Я.В. Капітальні інвестиції: сутність та проблеми реалізації в кризових умовах. Інвестииії: практика та досвід. 2015. № 21. С. 12-16.

8. Пересада А.А. , Майорова Т.В. Інвестиційне кредитування. К., 2002. $272 \mathrm{c}$.

9. Понедільчук Т. В. Аналіз динаміки капітальних інвестицій в економіці України. Науковий вісник Ужггородського університету. Сер.: Економіка. 2014. Вип. 1. C. 276-281.

10. Федоренко В. Г. Шляхи підвищення ефективності інвестицій в Україні. К. : Науковий Світ, 2003. 234 с.

11. Царенко О. В. Інвестиційні механізми реалізації цільової стратегії інноваційного розвитку легкої промисловості регіону. Інвестиції: практика та досвід. 2010. № 10. С. 9-13. URL:

http://nbuv.gov.ua/UJRN/ipd_2010_10_5 .

12. Шарп У. Ф. Инвестиции, М. : ИНФРА-М, 2000. 1024 с.

13. Шилова О. Ю. Оцінка економічний 
наслідків прийняття інвестиційних рішень підприємства. Маркетинг $i$ менеджмент інновачій. 2011. № 4(1). С. 126-131. URL: http://nbuv.gov.ua/UJRN/Mimi_2011_4(1)_1 9.

14. Аналіз сучасного стану інвестиційного забезпечення економіки України. Фінансово-економічна система України: сучасний стан та напрями розвитку: колективна монографія / за заг. ред. Попової О.Ю., Мариної А.С. Покровськ, ДВНЗ «ДоНТУ», 2019, 284 с.

15. Про інвестиційну діяльність: Закон України від 18.09.1991 р. №1560-XII зі змінами від № 3370-IV (3370-15) від 19.01.2006. Відомості Верховної Ради України. 2006. № 22. С. 184.

16. Державна служба статистики України [Електронний ресурс]. URL: http://www.ukrstat.gov.ua

17. Головне управління статистики в Донецькій області [Електронний ресурс]. URL:

http://donetskstat.gov.ua/statinform1/kap_inve st5.php

18. Головне управління статистики в Донецькій області [Електронний ресурс]. URL: http://donetskstat.gov.ua/statinform1/kap_inve st6.php

\section{References}

1. Blank I. O. (2003). Investment management: a textbook. 398. [in Ukrainian].

2. Hridasov V.M. Kryvchenko S.V., Isaieva O.Ye. (2004). Investment.164. [in Ukrainian].

3. Hryshova I. Yu. (2016) Investing strategies for innovative development of agricultural entities of Ukraine. Visnyk Sums'koho natsional'noho ahrarnoho universytetu. Seriya: Ekonomika i menedzhment.- 4, 11-15. Retrieved from: http://nbuv.gov.ua/UJRN/Vsna_ekon_2016_4_ 4. [in Ukrainian].

4. Katan L.I. (2011). Investments and investing as an economic category. Efektyvna ekonomika. $11 . \quad$ Retrieved from: http://nbuv.gov.ua/UJRN/efek_2011_11_32 [in Ukrainian].

5. Kisil M.I. (2014). Current challenges, strategic priorities and tasks for investment support of agricultural development. Innovatsiyna ekonomika. 50, 14 P. 19.
6. Kodenska M. Yu. (2013). Motivational factors of investment support for the development of agro-industrial production. Visnyk Akademiyi pratsi i sotsial'nykh vidnosyn Federatsiyi profspilok Ukrayiny. 2, 62-66. Retrieved from: http://nbuv.gov.ua/UJRN/VAPSV_2013_2_11.

7. Maiorova T.V. (2015). Capital investments: essence and problems of realization in crisis conditions [Text]. Investytsiyi: praktyka ta dosvid. 21, 12. P. 16.

8. Peresada A.A. (2002). Investment lending. 272.

9. Ponedilchuk, T. V. (2014). Analysis of the dynamics of capital investment in the economy of Ukraine. Naukovyi visnyk Uzhhorodskoho universytetu. Ser.: Ekonomika - Scientific Bulletin of Uzhgorod University. Sir: Economy, 1, 276-281 [in Ukrainian]

10. Fedorenko V. H. (2003). Ways to increase the efficiency of investments in Ukraine. 234.

11. Tsarenko O. V. (2010). Investment mechanisms for the implementation of the target strategy of innovative development of light industry in the region. Investytsiyi: praktyka ta dosvid. - 10, 9-13. - Retrieved from:http://nbuv.gov.ua/UJRN/ipd_2010_10_5 [in Ukrainian].

12. Sharp U. F. (2000). Investments. Textbooks. 1024. [in Russian].

13. Shylova O. Yu. (20.1) Assessment of the economic consequences of investment decisions of the enterprise. Marketynh $\mathrm{i}$ menedzhment innovatsiy. - 4 (1), $126-131$. Retrieved from: http://nbuv.gov.ua/UJRN/Mimi_2011_4(1)__1 9 [in Ukrainian].

14. Analysis of the current state of investment support of the Ukrainian economy. Financial and economic system of Ukraine: current state and directions of development: collective monograph. for general ed. Popova O.Yu., Marina A.S. - 2019. 284.

15. Law of Ukraine on investment activity №1560-XII (1991, September 18). Vidomosti Verkhovnoyi Rady Ukrayiny. 2006. 22, 184.

16. State Statistics Service of Ukraine [Electronic resource]. Retrieved from: http://www.ukrstat.gov.ua [in Ukrainian].

17. Main Department of Statistics in the Donetsk region [Electronic resource]. Retrieved from: http://donetskstat.gov.ua/statinform1/kap_inve 
st5.php [in Ukrainian].

18. Main Department of Statistics in the Donetsk region [Electronic resource]. -
Retrieved

from: http://donetskstat.gov.ua/statinform1/kap_inve st6.php [in Ukrainian].

Надійшла до редакиї 23.10.2019p.

Волкова Юлія Валеріївна - аспірантка кафедри управління і фінансово-економічної безпеки ДВНЗ «Донецький національний технічний університет»,

E-mail: yuliia.volkova@donntu.edu.ua

\section{CURRENT INVESTMENT TRENDS ECONOMIC ACTIVITY OF ENTERPRISES:}

Research of the current state and structure of capital investments both in Ukraine in general and in the Donetsk region in particular, in the period 2011 - 2019, identification of negative trends and prospects, indication of certain proposals for attracting investment resources. Methodology. The research methodology is generally based on the methods of system analysis, generalization and comparison. Results. The main provisions in the formulation of the concept of "investment" were indicated, the classification structure of investments on various grounds is given. The dynamics of changes in the volume of capital investment in the economy of Ukraine, and, in particular, in the economy of Donetsk region for the period 2011 - 2019, which in turn allowed to determine the causes of fluctuations. The analysis of the structure of capital investments by sources and types of economic activity of Donetsk region is carried out, certain conclusions are made about the changes that took place in the studied period. Recommendations for improving the efficiency of investment attraction are provided. Scientific novelty. The main factors that constrain the attraction of investment in the economy of Ukraine and in the economy of Donetsk region are given. The most priority branch of the region's economy for investors has been identified, and a structural analysis of capital investments in the region's economy has made it possible to find out at the expense of which funds the enterprises are renewing their fixed assets. There are some suggestions for effective investment. Prospects for investing in the national economy are substantiated. Practical significance. The results of the study form a practical basis for finding additional sources of investment in economic activity of industrial enterprises on a sustainable basis.

Keywords: sources of investment resources, economic activity, investments, investment development, climate, sustainable development, structure, business entities

Yuliia Volkova - graduate student of the department of management and financial and economic security, SHEE «Donetsk National Technical University»

E-mail: yuliia.volkova@donntu.edu.ua

\section{СОВРЕМЕННЫЕ ТЕНДЕНЦИИ ИНВЕСТИРОВАНИЯ ХОЗЯЙСТВЕННОЙ ДЕЯТЕЛЬНОСТИ ПРЕДПРИЯТИЙ}

Исследование современного состояния и структуры капитальных инвестищий как в Украине в целом, так и в Донеиком регионе, в частности, в период с 2011 по 2019 г2. Определение негативных тенденций и перспектив, указания определенных предложений по привлечению инвестиционных ресурсов. Методика. Методика исследования в целом базируется на методах системного анализа, обобщения и сравнения. Результаты. Были указаны основные положения по формулировке понятия «инвестиции», приведена классификаиионная структура инвестиций по различным признакам. Была исследована динамику изменения объемов капитальных инвестиций в экономику Украины и, в частности, в экономику Донеикой области за период с 2011 по 2019 гz.., что в свою очередь позволило выяснить причины колебаний показателей. Проведенный анализ структуры капитальных инвестиций по источникам финансирования и видам экономической деятельности Донеикой области позволил сделать определенные выводы об изменениях, которые произошли в исследуемый период. Даны рекомендации по улучшению эффективности привлечения инвестиций.

Научная новизна. Приведены основные факторы, сдерживающие привлечение инвестищий в экономику Украины, так и в экономику Донечкой области. Определена наиболее приоритетная отрасль экономики региона для инвесторов, проведенный структурный анализ капитальных инвестиций в 
экономику региона позволил выяснить за счет каких именно средств предприятия обновляют основные фонды. Указаны определенные предложения по эффективному привлечению инвестиций. Обоснованно перспективы инвестирования в национальную экономику. Практическая значимость. Результать исследования формируют практическую основу для поиска дополнительных источников инвестирования хозяйственной деятельности промышленных предприятий на основе постоянства.

Ключевые слова: источники инвестиционных ресурсов, экономическая деятельность, инвестиции, инвестиционное развитие, климат, устойчивое развитие, структура, субъекть хозяйствования

Юлия Волкова - аспирантка кафедры управления и финансово-экономической безопасности ГВУЗ «Донецкий национальный технический университет».

E-mail: yuliia.volkova@donntu.edu.ua 